\title{
Is there any Relationship between Urine Proteins and Cheek Dimples?
}

\author{
Muhammad Imran Qadir, Hafiz Muhammad Noman Ajmal* \\ Institute of Molecular Biology and Biotechnology, Bahauddin Zakariya University, Multan, Pakistan
}

*Corresponding Author: Hafiz Muhammad Noman Ajmal, Institute of Molecular Biology and Biotechnology, Bahauddin Zakariya University, Multan, Pakistan

\begin{abstract}
The objective of our present study was to identify the relationship between proteins and cheek dimples. A macromolecule in urine test measures what quantity protein is in your urine. Proteins are substances that are essential for your body to operate properly. Protein is generally found within the blood. If there's a controversy together with your kidneys, macromolecule will leak into your piss. Whereas a tiny low quantity is traditional, an oversized quantity of protein in urine could indicate renal disorder. Basically there are 2 kinds of dimples cheek and chin dimples. Dimples are literally deformation of skin muscles. Deformation in double feature muscle of face winds up among the formation of cheek dimples. It's as a cavity on cheeks after we tend to smile or build some facial expressions. Cheek dimples are shaped because of twisting of game muscle of face. Total 100 subjects participated throughout this activity that they were students. Then we've a bent to tend to gave them a plastic sterilized instrumentality and asked them to need their stuff sample at intervals the instrumentation. Then we've a bent to form a strive of lists, one list containing body waste protein levels of those persons who have cheek dimples and then the choice list containing urine protein levels of these persons who don't have cheek dimples. The conclusion of the present study is that there is no relation between urine protein and cheek dimples. Cheek dimples are mostly observed in those subjects who do not have cheek dimples.
\end{abstract}

Keywords: Urine Protein, Cheek dimples, Urinalysis, Protein test

\section{INTRODUCTION}

A macromolecule in urine test measures what quantity protein is in your urine. Proteins are substances that are essential for your body to operate properly. Protein is generally found within the blood. If there's a controversy together with your kidneys, macromolecule will leak into your piss. Whereas a tiny low quantity is traditional, an oversized quantity of protein in urine could indicate renal disorder. A macromolecule in urine check is commonly a part of a chemical analysis, a check that measures totally different cells, chemicals, and substances in your urine. Chemical analysis is commonly enclosed as a part of a routine test. This check may additionally be wont to search for or to observe renal disorder. If an oversized quantity of macromolecule is found in your urine sample, it doesn't essentially mean that you just have a medical drawback needing treatment. Strenuous exercise, diet, stress, pregnancy, and different factors will cause a brief rise in urine macromolecule levels. Your health care supplier could suggest further chemical analysis checks if a high level of macromolecule is found this testing may embrace a 24-hour piss sample test. If you may be doing all of your urine check reception, raise your health care supplier for recommendations on that check kit would be best for you. At-home urine tests are simple to try to and supply correct results as long as you rigorously follow all directions.

Basically there are 2 kinds of dimples cheek and chin dimples. Dimples are literally deformation of skin muscles. Deformation in double feature muscle of face winds up among the formation of cheek dimples. It's as a cavity on cheeks after we tend to smile or build some facial expressions. Cheek dimples are shaped because of twisting of game muscle of face. Cheek dimples seem on our face after we tend to smile and build some facial expression. Dimples could show up associated vanish over associate degree encompassing amount. Dimples are different by varieties at intervals the structure of the skeletal muscle observed as zygomaticus major. Specifically, the gap of a twofold or divided zygomaticus important muscle could clarify the arrangement of cheek dimples. This divided 
reasonably the muscle starts as a solitary structure from the bone. Dimple becomes visible as a hollow region on our cheek after we tend to smile. Dimples are transferred from individuals to offspring as a result of it's a genetic attribute. If everybody have dominant dimple genes than there would be one thousandth probability of getting dimples in their youngsters. Persons with homozygous dominant genes have dimples on either facet of their cheek and with heterozygous genes have dimple on one aspect of their cheek. In line with some individual dimple is associate irregular dominant attributed and it's controlled by another genes. In new born babies dimples seem because of the presence of body fats however dimples disappear once body fats becomes mature as a results of they're not genetic. It's inconceivable to induce eliminate dimples for good however we'll cut back their size by totally all other ways.

The objective of our present study was to identify the relationship between proteins and cheek dimples.

\section{Material AND MethodS}

\subsection{Project Designing}

Total 100 subjects participated throughout this activity that they were students. Initial of all we've a bent to tend to took permission from subjects calculate their body waste urine protein level through excretion take a glance at. Then we've a bent to tend to gave them a plastic sterilized instrumentality and asked them to need their stuff sample at intervals the instrumentation. We tend to tend to require their stuff sample then we've a bent to lord cramp excretion testing strip at intervals the instrumentality containing excretion sample for few seconds. We tend to tend to tend to attend specifically fifteen seconds, and match the check finish of the strip to the matter chart on the instrumentation. we've a bent to tend to took strip from instrumentality and not sleep for a second then match the given color of strip with colors written on the box and verify either it's negative or positive. Then we've a bent to tend to asked them whether or not or not or not or not they need cheek dimples or not and build a strive of lists. Then we've a bent to form a strive of lists, one list containing body waste protein levels of those persons who have cheek dimples and then the choice list containing urine protein levels of these persons who don't have cheek dimples.

\section{Statistical Analysis}

We simply calculate the percentage to analyze the given data to exclude our results.

\section{Results}

Table1. Relationship between Urine proteins (Percentage) and Cheek dimples.

\begin{tabular}{|c|c|c|c|c|}
\hline Having Dimples & Negative Protein & \multicolumn{3}{|c|}{ Positive Protein } \\
\hline Gender & -ve & $\mathbf{3 0}$ & $\mathbf{1 0 0}$ & $\mathbf{3 0 0}$ \\
\hline Male & $58 \%$ & $12 \%$ & $20 \%$ & $10 \%$ \\
\hline Female & $55 \%$ & $15 \%$ & $15 \%$ & $15 \%$ \\
\hline
\end{tabular}

Above table clears that negative protein in urine is mostly observed in both male and female subjects having cheek dimples. It means that there is no relation between urine protein and cheek dimples because positive urine protein is less than the negative.

Table2. Relationship between

\begin{tabular}{|c|c|c|c|c|}
\hline Not Having Dimples & Negative Protein & \multicolumn{3}{|c|}{ Positive Protein } \\
\hline Gender & -ve & $\mathbf{3 0}$ & $\mathbf{1 0 0}$ & $\mathbf{3 0 0}$ \\
\hline Male & $60 \%$ & $20 \%$ & $10 \%$ & $10 \%$ \\
\hline Female & $65 \%$ & $10 \%$ & $15 \%$ & $15 \%$ \\
\hline
\end{tabular}

Urine proteins (Percentage) and Cheek dimples.

Above table clears that negative protein in urine is mostly observed in both male and female subjects not having cheek dimples. It means that there is no relation between urine protein and cheek dimples because positive urine protein is less than the negative.

\section{DISCUSSION}

In Table 1, 42\% males with cheek dimples have positive urine protein level in pee level and one 58\% males have negative protein level. Female subjects have $45 \%$ positive and $55 \%$ negative urine protein 
level in piddle that has cheek dimples. Whereas in Table a pair of, males with no cheek dimples have $60 \%$ negative organic protein in piddle level and 40 percent males have excretory product protein level in urine. Female subjects with no cheek dimples have 35\% and 65\% negative protein in pee.

A previous study offers us info that there was a relation between people and cheek dimples. O+ individual's folks have most chance of getting cheek dimples on their face. And there was no scientific relation among glucose level and cheek dimples as results of p price is in addition a smaller amount than .05 and results were non-significant place on reportable in previous studies.

\section{CONCLUSION}

The conclusion of the present study is that there is no relation between urine protein and cheek dimples. Cheek dimples are mostly observed in those subjects who do not have cheek dimples.

\section{REFERENCES}

[1] Kirby T, Baloa LA, Witt EK, inventors; RIC INVESTMENTS LLC, assignee. Systems and methods for controlling breathing rate. United States patent US 7,556,038. 2009 Jul 7.

[2] Stevens ED, Randall DJ. Changes in blood pressure, heart rate and breathing rate during moderate swimming activity in rainbow trout. Journal of Experimental Biology. 1967 Apr 1;46(2):307-15.

[3] Bernardi L, Spadacini G, Bellwon J, Hajric R, Roskamm H, Frey AW. Effect of breathing rate on oxygen saturation and exercise performance in chronic heart failure. The Lancet. 1998 May 2;351(9112):1308-11.

[4] Tarassenko L, Mason CL, inventors; Oxford University Innovation Ltd, assignee. Combining measurements from breathing rate sensors. United States patent US 7,318,808. 2008 Jan 15.

[5] Qadir MI, Javid A (2018) Awareness about Crohn's Disease in biotechnology students. GloAdv Res J Med Medical Sci, 7(3): 062-064.

[6] Qadir MI, Saleem A (2018) Awareness about ischemic heart disease in university biotechnology students. GloAdv Res J Med Medical Sci, 7(3): 059-061.

[7] Qadir MI, Ishfaq S (2018) Awareness about hypertension in biology students. Int J Mod Pharma Res, 7(2): 08-10.

[8] Qadir MI, Mehwish (2018) Awareness about psoriasis disease. Int J Mod Pharma Res, 7(2): 17-18.

[9] Qadir MI, Shahzad R (2018) Awareness about obesity in postgraduate students of biotechnology. Int J Mod Pharma Res, 7(2): 14-16.

[10] Qadir MI, Rizvi M (2018) Awareness about thalassemia in post graduate students. MOJ Lymphology \& Phlebology, 2(1): 14-16.

[11] Qadir MI, Ghalia BA (2018) Awareness survey about colorectal cancer in students of M. Phil Biotechnology at Bahauddin Zakariya University, Multan, Pakistan. Nov Appro in Can Study, 1(3): NACS.000514.2018.

[12] Qadir MI, Saba G (2018) Awareness about intestinal cancer in university student. Nov Appro in Can Study, 1(3): NACS.000515.2018.

Citation: Muhammad Imran Qadir, Hafiz Muhammad Noman Ajmal, "Is there any Relationship between Urine Proteins and Cheek Dimples?" International Journal of Research Studies In Biosciences (Ijrsb), Vol. 7, no. 8, pp. 1-3, 2019. http://Dx.Doi.org/10.20431/2349-0365.0708001

Copyright: () 2019 Authors. This is an open-access article distributed under the terms of the Creative Commons Attribution License, which permits unrestricted use, distribution, and reproduction in any medium, provided the original author and source are credited. 